\author{
Dustin K. Smith, DO, \\ FAAFP; Stephen M. \\ McMullan, MD; Matthew \\ J. Martin, DO \\ Jacksonville Family Medicine \\ Residency Program, Naval \\ Hospital Jacksonville, FL \\ (Drs. Smith and Martin); \\ Mayo Clinic Florida, \\ Jacksonville (Dr. McMullan); \\ Uniformed Services \\ University of Health \\ Sciences, Bethesda, MD \\ (Dr. Smith)

\section{Edustinksmith@yahoo.} \\ com \\ The authors reported no \\ potential conflict of interest \\ relevant to this article. \\ The views expressed in this article \\ are those of the authors and do \\ not necessarily reflect the official \\ policy or position of the \\ US Department of the Navy, \\ US Department of Defense, or \\ the government of the United \\ States.
}

doi: 10.12788/jfp.0201

\title{
Getting hypertension under control in the youngest of patients
}

\author{
After confirmation of the diagnosis, follow up with \\ recommendations for lifestyle adjustment and, in certain \\ clinical situations, pursue medical therapy.
}

\section{PRACTICE \\ RECOMMENDATIONS}

> Measure the blood pressure (BP) of all children 3 years and older annually; those who have a specific comorbid condition (eg, obesity, diabetes, renal disease, or an aortic-arch abnormality) or who are taking medication known to elevate BP should have their BP checked at every health care visit. (C)

> Encourage lifestyle modification as the initial treatment for elevated BP or hypertension in children. (A)

> Utilize pharmacotherapy for (1) children with stage 1 hypertension who have failed to meet BP goals after 3 to 6 months of lifestyle modification and (2) children with stage 2 hypertension who do not have a modifiable risk factor, such as obesity. (c)
Strength of recommendation (SOR)
A Good-quality patient-oriented evidence
(B) Inconsistent or limited-quality patient-oriented evidence C Consensus, usual practice,
opinion, disease-oriented evidence, case series

$\mathrm{H}$ ypertension and elevated blood pressure (BP) in children and adolescents correlate to hypertension in adults, insofar as complications and medical therapy increase with age. ${ }^{1,2}$ Untreated, hypertension in children and adolescents can result in multiple harmful physiologic changes, including left ventricular hypertrophy, left atrial enlargement, diastolic dysfunction, arterial stiffening, endothelial dysfunction, and neurocognitive deficits. ${ }^{3-5}$

In 2017, the American Academy of Pediatrics (AAP) published clinical practice guidelines for the diagnosis and management of elevated BP and hypertension in children and adolescents ${ }^{\mathrm{a}}$ (TABLE $1^{6}$ ). Applying the definition of elevated BP set out in these guidelines yielded a $13 \%$ prevalence of hypertension in a cohort of subjects 10 to 18 years of age with comorbid obesity and diabetes mellitus (DM). AAP guideline definitions also improved the sensitivity for identifying hypertensive end-organ damage.?

As the prevalence of hypertension increases, screening for and accurate diagnosis of this condition in children are becoming more important. Recognition and management remain a vital part of primary care. In this article, we review the updated guidance on diagnosis and treatment, including lifestyle modification and pharmacotherapy.

\section{First step: Identifying hypertension Risk factors}

Risk factors for pediatric hypertension are similar to those in adults. These include obesity (body mass index $\geq 95$ th percentile for age), types 1 and $2 \mathrm{DM}$, elevated sodium intake, sleep-

${ }^{a}$ AAP guidelines on the management of pediatric hypertension vary from those of the US Preventive Services Task Force. See the Practice Alert, "A review of the latest USPSTF recommendations," in the May 2021 issue at https://www.mdedge.com/ familymedicine/article/240051/pediatrics/review-latest-uspstf-recommendations 


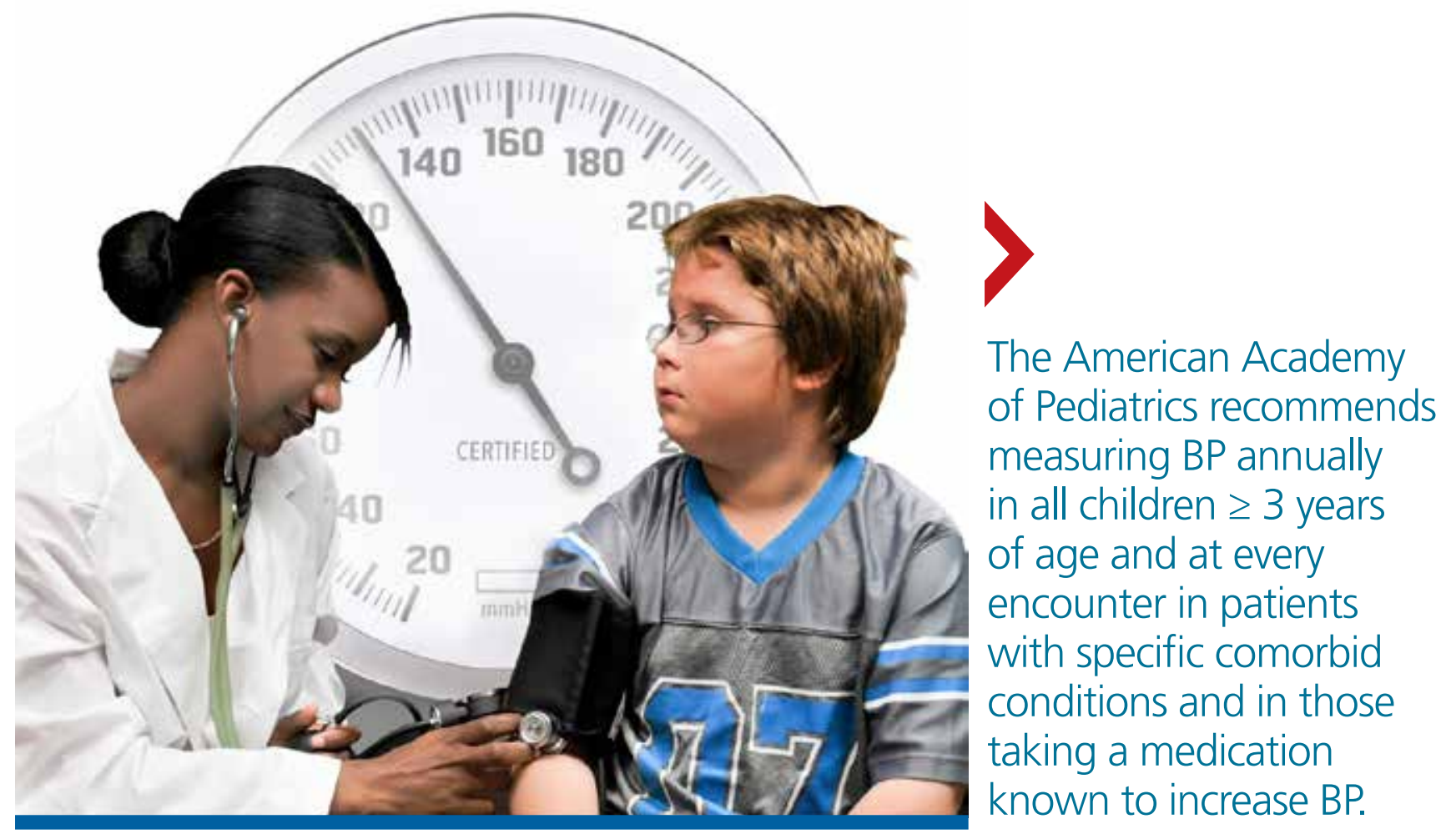

disordered breathing, and chronic kidney disease (CKD). Some risk factors, such as premature birth and coarctation of the aorta, are specific to the pediatric population..$^{8-14} \mathrm{Pe}$ diatric obesity strongly correlates with both pediatric and adult hypertension, and accelerated weight gain might increase the risk of elevated BP in adulthood. ${ }^{15,16}$

Intervening early to mitigate or eliminate some of these modifiable risk factors can prevent or treat hypertension. ${ }^{17}$ Alternatively, having been breastfed as an infant has been reliably shown to reduce the risk of elevated $\mathrm{BP}$ in children. ${ }^{13}$

\section{Recommendations} for screening and measuring BP

The optimal age to start measuring $\mathrm{BP}$ is not clearly defined. AAP recommends measurement:

- annually in all children $\geq 3$ years of age

- at every encounter in patients who have a specific comorbid condition, including obesity, DM, renal disease, and aortic-arch abnormalities (obstruction and coarctation) and in those who are taking medication known to increase BP. ${ }^{6}$

I Protocol. Measure BP in the right arm for consistency and comparison with reference values. The width of the cuff bladder should be at least $40 \%$, and the length, $80 \%$ to $100 \%$, of arm circumference. Position the cuff bladder midway between the olecranon and acromion. Obtain the measurement in a quiet and comfortable environment after the patient has rested for 3 to 5 minutes. The patient should be seated, preferably with feet on the floor; elbows should be supported at the level of the heart.

When an initial reading is elevated, whether by oscillometric or auscultatory measurement, 2 more auscultatory BP measurements should be taken during the same visit; these measurements are averaged to determine the BP category. ${ }^{18}$

TABLE $1^{6}$ defines BP categories based on age, sex, and height. We recommend using the free resource MD Calc (www.mdcalc.com/ aap-pediatric-hypertension-guidelines) to assist in calculating the BP category.

TABLE $2^{6}$ describes the timing of follow-up based on the initial BP reading and diagnosis.

I Ambulatory BP monitoring (ABPM) is a validated device that measures BP every 20 to 30 minutes throughout the day and night. ABPM should be performed initially in all patients with persistently elevated BP and 
Children older than 10 years who have been given a diagnosis of hypertension should be asked about smoking, alcohol, and other substance use.

\section{TABLE 1}

\section{Classification of normal and elevated BP and hypertension in children ${ }^{6}$}

\begin{tabular}{|c|c|c|}
\hline \multirow[b]{2}{*}{ Category } & \multicolumn{2}{|c|}{ Age } \\
\hline & $1-12 y$ & $\geq 13 y$ \\
\hline Normal BP & $<90$ th percentile ${ }^{a}$ & $<120 / 80 \mathrm{~mm} \mathrm{Hg}$ \\
\hline Elevated BP & $\begin{array}{l}\text { Whichever is lower: } \\
\geq 90 \text { th percentile to }<95 \text { th percentile } \\
\text { or } \\
120 / 80 \mathrm{~mm} \mathrm{Hg} \text { to }<95 \text { th percentile }\end{array}$ & $120 /<80 \mathrm{~mm} \mathrm{Hg}$ to $129 /<80 \mathrm{~mm} \mathrm{Hg}$ \\
\hline Stage 1 hypertension & $\begin{array}{l}\text { Whichever is lower: } \\
\geq 95 \text { th percentile to } \leq 95 \text { th percentile } \\
+12 \mathrm{~mm} \mathrm{Hg} \text { (systolic or diastolic } \\
\text { pressure) } \\
\text { or } \\
130 / 80 \mathrm{~mm} \mathrm{Hg} \text { to } 139 / 89 \mathrm{~mm} \mathrm{Hg}\end{array}$ & $130 / 80 \mathrm{~mm} \mathrm{Hg}$ to $139 / 89 \mathrm{~mm} \mathrm{Hg}$ \\
\hline Stage 2 hypertension & $\begin{array}{l}\text { Whichever is lower: } \\
\geq 95 \text { th percentile }+12 \mathrm{~mm} \mathrm{Hg} \text { (systolic } \\
\text { or diastolic pressure) } \\
\text { or } \\
\geq 140 / 90 \mathrm{~mm} \mathrm{Hg}\end{array}$ & $\geq 140 / 90 \mathrm{~mm} \mathrm{Hg}$ \\
\hline
\end{tabular}

BP, blood pressure.

${ }^{\text {a } A l l ~ p e r c e n t i l e s ~ g i v e n ~ h e r e ~ a r e ~ c a l c u l a t e d ~ b a s e d ~ o n ~ a g e, ~ s e x, ~ a n d ~ h e i g h t ~(s e e: ~ w w w . m d c a l c . c o m / a a p-p e d i a t r i c-h y p e r t e n s i o n-~}$ guidelines).

routinely in children and adolescents with a high-risk comorbidity (TABLE $2^{6}$ ). Note: Insurance coverage of ABPM is limited.

ABPM is also used to diagnose socalled white-coat hypertension, defined as $\mathrm{BP} \geq 95$ th percentile for age, sex, and height in the clinic setting but $<$ 95th percentile during ABPM. This phenomenon can be challenging to diagnose.

I Home monitoring. Do not use home BP monitoring to establish a diagnosis of hypertension, although one of these devices can be used as an adjunct to office and ambulatory BP monitoring after the diagnosis has been made. ${ }^{6}$

\section{Evaluating hypertension in children and adolescents}

Once a diagnosis of hypertension has been made, undertake a thorough history, physical examination, and diagnostic testing to evaluate for possible causes, comorbidities, and any evidence of end-organ damage.
I Comprehensive history. Pertinent aspects include perinatal, nutritional, physical activity, psychosocial, family, medicationand of course, medical-histories. ${ }^{6}$

Maternal elevated BP or hypertension is related to an offspring's elevated $\mathrm{BP}$ in childhood and adolescence. ${ }^{19}$ Other pertinent aspects of the perinatal history include complications of pregnancy, gestational age, birth weight, and neonatal complications. ${ }^{6}$

Nutritional and physical activity histories can highlight contributing factors in the development of hypertension and can be a guide to recommending lifestyle modifications. ${ }^{6}$ Sodium intake, which influences BP, should be part of the nutritional history. ${ }^{20}$

Important aspects of the psychosocial history include feelings of depression or anxiety, bullying, and body perception. Children older than 10 years should be asked about smoking, alcohol, and other substance use.

The family history should include notation of first- and second-degree relatives 
TABLE 2

\section{Initial measurement of BP determines the timing and elements of follow-up ${ }^{6}$}

\begin{tabular}{|c|c|c|c|c|c|c|c|}
\hline $\begin{array}{l}\text { BP category } \\
\left(\text { see TABLE } 1^{6} \text { ) }\right.\end{array}$ & $\begin{array}{l}\text { BP screening } \\
\text { schedule }\end{array}$ & $\begin{array}{l}\text { Lifestyle } \\
\text { counseling } \\
\text { (weight and } \\
\text { nutrition) }\end{array}$ & $\begin{array}{l}\text { Check upper- } \\
\text { and lower- } \\
\text { extremity BP }\end{array}$ & $\mathrm{ABPM}^{\mathrm{a}}$ & $\begin{array}{l}\text { Diagnostic } \\
\text { evaluation }^{\mathrm{b}}\end{array}$ & $\begin{array}{l}\text { Initiate } \\
\text { treatment }^{c}\end{array}$ & $\begin{array}{l}\text { Consider } \\
\text { subspecialty } \\
\text { referral }\end{array}$ \\
\hline Normal & Annual & $x$ & - & - & - & - & - \\
\hline \multirow[t]{3}{*}{ Elevated BP } & Initial measurement & $x$ & - & - & - & - & - \\
\hline & $\begin{array}{l}\text { Second measurement: } \\
\text { Repeat in } 6 \text { mo }\end{array}$ & $x$ & $\mathrm{X}$ & - & - & - & - \\
\hline & $\begin{array}{l}\text { Third measurement: } \\
\text { Repeat in } 6 \text { mo }\end{array}$ & $X$ & - & $\mathrm{X}$ & $\mathrm{x}$ & - & $\mathrm{X}$ \\
\hline \multirow[t]{3}{*}{ Stage $1 \mathrm{HTN}$} & Initial measurement & $x$ & - & - & - & - & - \\
\hline & $\begin{array}{l}\text { Second measurement: } \\
\text { Repeat in } 1-2 \text { wk }\end{array}$ & $X$ & $x$ & - & - & - & - \\
\hline & $\begin{array}{l}\text { Third measurement: } \\
\text { Repeat in } 3 \text { mo }\end{array}$ & $x$ & - & $x$ & $x$ & $x$ & $x$ \\
\hline \multirow[t]{2}{*}{ Stage 2 HTN $^{d}$} & Initial measurement & $x$ & $X$ & - & - & - & - \\
\hline & $\begin{array}{l}\text { Second measurement: } \\
\text { Repeat, refer to } \\
\text { specialty care within } \\
1 \text { wk }\end{array}$ & $X$ & - & $x$ & $x$ & $x$ & $x$ \\
\hline
\end{tabular}

ABPM, ambulatory blood pressure monitoring; BP, blood pressure; HTN, hypertension.

${ }^{a} A B P M$ is done to confirm HTN before initiating a diagnostic evaluation.

${ }^{\mathrm{b}}$ TABLE $3^{6,23}$ describes the diagnostic evaluation.

'Treatment may be initiated by a primary care provider or subspecialist.

${ }^{d}$ If the patient is symptomatic or BP is $>30 \mathrm{~mm} \mathrm{Hg}$ above the 95 th percentile (or $>180 / 120 \mathrm{~mm} \mathrm{Hg}$ in an adolescent), send to an emergency department.

Reproduced with permission from Pediatrics, vol. 140, page e20171904. Copyright @ 2017 by the American Academy of Pediatrics.

with hypertension. ${ }^{6}$

Inquire about medications that can raise $\mathrm{BP}$, including oral contraceptives, which are commonly prescribed in this population. ${ }^{21,22}$

- The physical exam should include measured height and weight, with calculation of the body mass index percentile for age; of note, obesity is strongly associated with hypertension, and poor growth might signal underlying chronic disease. Once elevated BP has been confirmed, the exam should include measurement of $\mathrm{BP}$ in both arms and in a leg (TABLE $2^{6}$ ). BP that is lower in the leg than in the arms (in any given patient, BP readings in the legs are usually higher than in the arms), or weak or absent femoral pulses, suggest coarctation of the aorta. ${ }^{6}$

Focus the balance of the physical exam on physical findings that suggest secondary causes of hypertension or evidence of endorgan damage.

ITesting. TABLE $3^{6,23}$ summarizes the diagnostic testing recommended for all children and for specific populations; TABLE $2^{6}$ indicates when to obtain diagnostic testing. Patients 6 years and older who are overweight or obese and have a family history of hypertension likely have primary hypertension; they do not require an extensive work-up for secondary hypertension unless findings of the comprehensive history and physical examination lead in that direction. ${ }^{6,23}$

TABLE $4^{2,12,13,24}$ outlines the basis of primary and of secondary hypertension and common historical and physical findings that suggest a secondary cause.

\section{Mapping out the treatment plan}

Pediatric hypertension should be treated in patients with stage 1 or higher hypertension. ${ }^{6}$ This threshold for therapy is based on evidence that reducing BP below a goal of (1) the 90th percentile (calculated based 


\section{Ambulatory BP monitoring should be performed initially in all patients with persistently elevated BP and routinely in children and adolescents with a high-risk comorbidity.}

TABLE 3

\section{Diagnostic testing in children with hypertension ${ }^{6,23}$}

\begin{tabular}{|c|c|}
\hline Population and test & Instructions and rationale \\
\hline \multicolumn{2}{|l|}{ All patients } \\
\hline Chemistry panel & $\begin{array}{l}\text { Include measurement of electrolytes, blood urea nitrogen, } \\
\text { and creatinine }\end{array}$ \\
\hline Echocardiogram & $\begin{array}{l}\text { Order only when pharmacotherapeutic intervention is } \\
\text { being considered }\end{array}$ \\
\hline Lipid panel & Specimen can be drawn in a fasting or nonfasting state \\
\hline \multicolumn{2}{|l|}{ Urinalysis } \\
\hline \multicolumn{2}{|l|}{ Obese patients ${ }^{\mathrm{a}}$} \\
\hline $\begin{array}{l}\text { Alanine aminotransferase and } \\
\text { aspartate aminotransferase }\end{array}$ & Screen for fatty liver disease \\
\hline Fasting lipid panel & Screen for dyslipidemia \\
\hline Hemoglobin A1C & Screen for diabetes \\
\hline \multicolumn{2}{|l|}{ Optional' } \\
\hline Complete blood count & $\begin{array}{l}\text { Order when a history of growth delay has been reported or } \\
\text { results of renal function testing are abnormal }\end{array}$ \\
\hline Drug screen & Order when the history suggests substance abuse \\
\hline Fasting serum glucose & Order when the patient is at high risk of diabetes \\
\hline \multirow[t]{2}{*}{ Renal doppler ultrasound } & $\begin{array}{l}\text { Should be performed in a child }<6 \text { y or who has abnormal } \\
\text { urinalysis or renal function }\end{array}$ \\
\hline & $\begin{array}{l}\text { Consider performing in a normal-weight child } \geq 8 \text { y } \\
\text { in whom renovascular hypertension is suspected }\end{array}$ \\
\hline Sleep study & $\begin{array}{l}\text { Order when a history of loud snoring or daytime sleepiness } \\
\text { has been reported }\end{array}$ \\
\hline Thyroid-stimulating hormone & \\
\hline
\end{tabular}

on age, sex, and height) in children up to 12 years of age or (2) of $<130 / 80 \mathrm{~mm} \mathrm{Hg}$ for children $\geq 13$ years reduces short- and longterm morbidity and mortality. ${ }^{5,6,25}$

Choice of initial treatment depends on the severity of BP elevation and the presence of comorbidities (FIGURE ${ }^{6,20,25-28}$ ). The initial, fundamental treatment recommendation is lifestyle modification, ${ }^{6,29}$ including regular physical exercise, a change in nutritional habits, weight loss (because obesity is a common comorbid condition), elimination of tobacco and substance use, and stress reduction..$^{25,26}$ Medications can be used as well, along with other treatments for specific causes of secondary hypertension.

Referral to a specialist can be considered if consultation for assistance with treatment is preferred (TABLE $2^{6}$ ) or if the patient has:
- treatment-resistant hypertension

- stage 2 hypertension that is not quickly responsive to initial treatment

- an identified secondary cause of hypertension.

\section{Lifestyle modification}

\section{can make a big difference}

I Exercise. "Regular" physical exercise for children to reduce BP is defined as $\geq 30$ to 60 minutes of active play daily. ${ }^{6,29}$ Studies have shown significant improvement not only in BP but also in other cardiovascular disease risk parameters with regular physical exercise. ${ }^{27} \mathrm{~A}$ study found that the reduction in systolic BP is, on average, approximately $6 \mathrm{~mm} \mathrm{Hg}$ with physical activity alone. ${ }^{30}$

I Nutrition. DASH-Dietary Approaches to Stop Hypertension-is an evidence-based 
TABLE 4

What is the etiology of pediatric hypertension? 2,12,13,24

\begin{tabular}{|c|c|}
\hline Cause & Findings on the history and physical examination \\
\hline \multicolumn{2}{|l|}{ Primary hypertension } \\
\hline \multirow[t]{2}{*}{ Essential } & Family history of hypertension \\
\hline & Overweight, obesity \\
\hline \multicolumn{2}{|l|}{ Secondary hypertension ${ }^{a}$} \\
\hline Coarctation & $\begin{array}{l}\text { Diminished femoral pulses, heart murmur, lower blood pressure } \\
\text { in a leg than in either arm }\end{array}$ \\
\hline \multirow[t]{2}{*}{ Cushing syndrome } & Family history of an endocrine disorder \\
\hline & Acne, hirsutism, moon facies, striae, truncal obesity \\
\hline Drug- and substance-induced & $\begin{array}{l}\text { Cocaine, corticosteroids, decongestants, diet aids, oral } \\
\text { contraceptives, stimulants (amphetamines, caffeine) }\end{array}$ \\
\hline \multirow[t]{2}{*}{ Hyperthyroidism } & Family history of thyroid disorder \\
\hline & Heat intolerance, pallor, rash, sweating, tachycardia, weight loss \\
\hline \multirow[t]{2}{*}{ Mineralocorticoid excess } & Family history of an endocrine disorder \\
\hline & Ambiguous genitalia, muscle weakness \\
\hline Pheochromocytoma & Flushing, pallor, palpitations, tachycardia \\
\hline \multirow[t]{2}{*}{ Renal artery stenosis } & History of umbilical artery catheterization \\
\hline & Abdominal bruit \\
\hline \multirow[t]{2}{*}{ Renal parenchymal disease } & Family history of renal disease \\
\hline & $\begin{array}{l}\text { Abdominal mass, edema, enuresis, fatigue, gross hematuria, } \\
\text { growth retardation, recurrent urinary tract infection }\end{array}$ \\
\hline \multirow[t]{2}{*}{ Rheumatologic disorder } & Family history of autoimmune disease \\
\hline & Fatigue, friction rub, joint pain or swelling, rash \\
\hline \multirow[t]{2}{*}{ Sleep-disordered breathing } & Family history of obstructive sleep apnea \\
\hline & Snoring, tonsillar hypertrophy \\
\hline
\end{tabular}

${ }^{\text {a }}$ Defined as hypertension that is caused by an underlying disorder.

program to reduce BP. This nutritional guideline focuses on a diet rich in natural foods, including fruits, vegetables, minimally processed carbohydrates and whole grains, and low-fat dairy and meats. It also emphasizes the importance of avoiding foods high in processed sugars and reducing sodium intake. ${ }^{31}$ Higher-than-recommended sodium intake, based on age and sex (and established as part of dietary recommendations for children on the US Department of Health and Human Services' website health.gov) directly correlates with the risk of prehypertension and hypertension-especially in overweight and obese children. ${ }^{20,32}$ DASH has been shown to reliably reduce the incidence of hypertension in children; other studies have supported increased intake of fruits, vegetables, and legumes as strategies to reduce $\mathrm{BP}^{33,34}$

I Other interventions. Techniques to improve adherence to exercise and nutritional modifications for children include motivational interviewing, community programs and education, and family counseling. ${ }^{27,35}$ A recent study showed that a communitybased lifestyle modification program that is focused on weight loss in obese children resulted in a significant reduction in BP values at higher stages of obesity. ${ }^{36}$ There is evidence that techniques such as controlled breathing
The family history should include notation of first- and second-degree relatives with hypertension. Inquire about medications that can raise $\mathrm{BP}_{1}$ including oral contraceptives. 


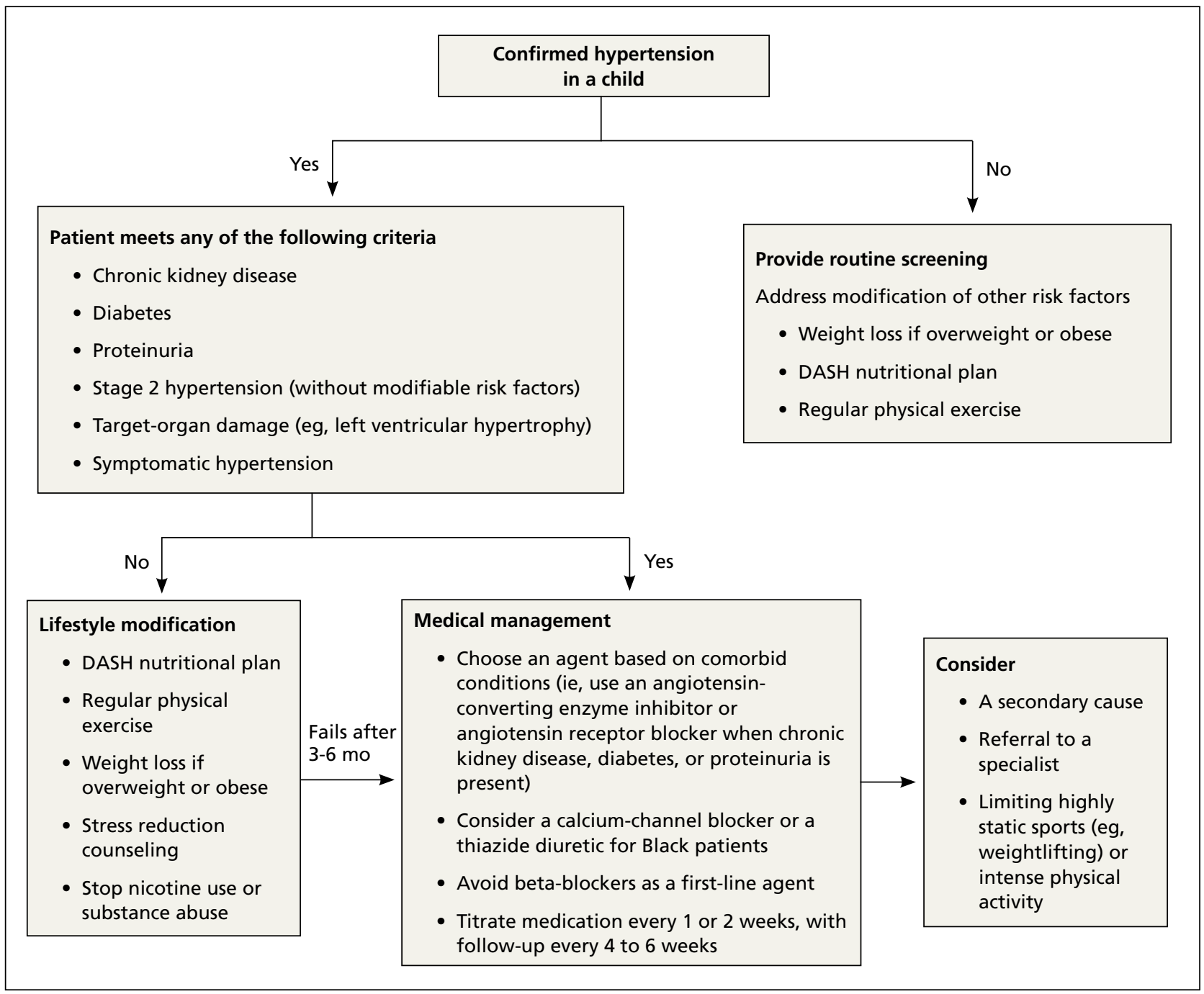

DASH, Dietary Approaches to Stop Hypertension.

and meditation can reduce $\mathrm{BP} .^{37}$ Last, screening and counseling to encourage tobacco and substance use discontinuation are recommended for children and adolescents to improve health outcomes. ${ }^{25}$

\section{Proceed with pharmacotherapy when these criteria are met}

Medical therapy is recommended when certain criteria are met, although this decision should be individualized and made in agreement by the treating physician, patient, and family. These criteria (FIGURE ${ }^{6,20,25-28}$ ) are $^{6,29}$ :

- once a diagnosis of stage 1 hyperten- sion has been established, failure to meet a BP goal after 3 to 6 months of attempting lifestyle modifications

- stage 2 hypertension without a modifiable risk factor, such as obesity

- any stage of hypertension with comorbid CKD, DM, or proteinuria

- target-organ damage, such as left ventricular hypertrophy

- symptomatic hypertension. ${ }^{6,29}$

There are circumstances in which one or another specific antihypertensive agent is recommended for children; however, for 
most patients with primary hypertension, the following classes are recommended for firstline use ${ }^{6,22}$ :

- angiotensin-converting enzyme (ACE) inhibitors

- angiotensin receptor blockers (ARBs)

- calcium-channel blockers (CCBs)

- thiazide diuretics.

For a child with known CKD, DM, or proteinuria, an ACE inhibitor or ARB is beneficial as first-line therapy. ${ }^{38}$ Because ACE inhibitors and ARBs have teratogenic effects, however, a thorough review of fertility status is recommended for female patients before any of these agents are started. CCBs and thiazides are typically recommended as first-line agents for Black patients. ${ }^{6,28}$ Beta-blockers are typically avoided in the first line because of their adverse effect profile.

Most antihypertensive medications can be titrated every 1 or 2 weeks; the patient's BP can be monitored with a home BP cuff to track the effect of titration. In general, the patient should be seen for follow-up every 4 to 6 weeks for a BP recheck and review of medication tolerance and adverse effects. Once the treatment goal is achieved, it is reasonable to have the patient return every 3 to 6 months to reassess the treatment plan.

If the BP goal is difficult to achieve despite titration of medication and lifestyle changes, consider repeat ABPM assessment, a specialty referral, or both. It is reasonable for children who have been started on medication and have adhered to lifestyle modifications to practice a "step-down" approach to discontinuing medication; this approach can also be considered once any secondary cause has been corrected. Any target-organ abnormalities identified at diagnosis (eg, proteinuria, CKD, left ventricular hypertrophy) need to be reexamined at follow-up. ${ }^{6}$

\section{Restrict activities- or not?}

There is evidence that a child with stage 1 or well-controlled stage 2 hypertension without evidence of end-organ damage should not have restrictions on sports or activity. However, in uncontrolled stage 2 hypertension or when evidence of target end-organ damage is present, you should advise against participation in highly competitive sports and highly static sports (eg, weightlifting, wrestling), based on expert opinion ${ }^{6,25}\left(\right.$ FIGURE $\left.^{6,20,25-28}\right)$. JFP

\section{CORRESPONDENCE}

Dustin K. Smith, MD, Family Medicine Department, 2080 Child Street, Jacksonville, FL, 32214;

dustinksmith@yahoo.com

\section{References}

1. Theodore RF, Broadbent J, Nagin D, et al. Childhood to early-midlife systolic blood pressure trajectories: earlylife predictors, effect modifiers, and adult cardiovascular outcomes. Hypertension. 2015;66:1108-1115. doi: 10.1161/ HYPERTENSIONAHA.115.05831

2. Lurbe E, Agabiti-Rosei E, Cruickshank JK, et al. 2016 European Society of Hypertension guidelines for the management of high blood pressure in children and adolescents. J Hypertens. 2016;34:1887-1920. doi: 10.1097/HJH.0000000000001039

3. Weaver DJ, Mitsnefes MM. Effects of systemic hypertension on the cardiovascular system. Prog Pediatr Cardiol. 2016;41:59-65. https://doi.org/10.1016/j.ppedcard.2015.11.005

4. Ippisch HM, Daniels SR. Hypertension in overweight and obese children. Prog Pediatr Cardiol. 2008;25:177-182. doi: $\mathrm{org} / 10.1016 /$ j.ppedcard.2008.05.002

5. Urbina EM, Lande MB, Hooper SR, et al. Target organ abnormalities in pediatric hypertension. J Pediatr. 2018;202:14-22. doi: 10.1016/j.jpeds.2018.07.026

6. Flynn JT, Kaelber DC, Baker-Smith CM, et al; Subcommittee on Screening and Management of High Blood Pressure in Children. Clinical practice guideline for screening and management of high blood pressure in children and adolescents. Pediatrics. 2017;140:e20171904. doi: 10.1542/peds.2017-1904

7. Khoury M, Khoury PR, Dolan LM, et al. Clinical implications of the revised AAP pediatric hypertension guidelines. Pediatrics. 2018;142:e20180245. doi: 10.1542/peds.2018-0245

8. Falkner B, Gidding SS, Ramirez-Garnica G, et al. The relationship of body mass index and blood pressure in primary care pediatric patients. J Pediatr. 2006;148:195-200. doi: 10.1016/ j.jpeds.2005.10.030

9. Rodriguez BL, Dabelea D, Liese AD, et al; SEARCH Study Group. Prevalence and correlates of elevated blood pressure in youth with diabetes mellitus: the SEARCH for diabetes in youth study. J Pediatr. 2010;157:245-251.e1. doi: 10.1016/j.jpeds.2010.02.021

10. Shay CM, Ning H, Daniels SR, et al. Status of cardiovascular health in US adolescents: prevalence estimates from the National Health and Nutrition Examination Surveys (NHANES) 2005-2010. Circulation. 2013;127:1369-1376. doi: 10.1161/ CIRCULATIONAHA.113.001559

11. Archbold KH, Vasquez MM, Goodwin JL, et al. Effects of sleep patterns and obesity on increases in blood pressure in a 5-year period: report from the Tucson Children's Assessment of Sleep Apnea Study. J Pediatr. 2012;161:26-30. doi: 10.1016/ j.jpeds.2011.12.034

12. Flynn JT, Mitsnefes M, Pierce C, et al; Chronic Kidney Disease in Children Study Group. Blood pressure in children with chronic kidney disease: a report from the Chronic Kidney Disease in Children study. Hypertension. 2008;52:631-637. doi: 10.1161/ HYPERTENSIONAHA.108.110635

13. Martin RM, Ness AR, Gunnell D, et al; ALSPAC Study Team. Does breast-feeding in infancy lower blood pressure in childhood? The Avon Longitudinal Study of Parents and Children (ALSPAC). Circulation. 2004;109:1259-1266. doi: 10.1161/01. CIR.0000118468.76447.CE

14. Brickner ME, Hillis LD, Lange RA. Congenital heart disease in adults. $N$ Engl J Med. 2000;342:256-263. doi: 10.1056/ NEJM200001273420407

15. Chen X, Wang Y. Tracking of blood pressure from childhood to adulthood: a systematic review and meta-regression analysis. Circulation. 2008;117:3171-3180. doi: 10.1161/ CIRCULATIONAHA.107.730366

16. Sun SS, Grave GD, Siervogel RM, et al. Systolic blood pressure in childhood predicts hypertension and metabolic syndrome later in life. Pediatrics. 2007;119:237-246. doi: 10.1542/peds.2006-2543

CONTINUED
The initial, fundamental treatment recommendation is lifestyle modification, including regular physical exercise, a change in nutritional habits, and weight loss. 
17. Parker ED, Sinaiko AR, Kharbanda EO, et al. Change in weight status and development of hypertension. Pediatrics. 2016; 137:e20151662. doi: 10.1542/peds.2015-1662

18. Pickering TG, Hall JE, Appel LJ, et al; Subcommittee of Professional and Public Education of the American Heart Association Council on High Blood Pressure Research. Recommendations for blood pressure measurement in humans and experimental animals: Part 1: blood pressure measurement in humans: a statement for professionals from the Subcommittee of Professional and Public Education of the American Heart Association Council on High Blood Pressure Research. Hypertension. 2005;45: 142-161. doi: 10.1161/01.HYP.0000150859.47929.8e

19. Staley JR, Bradley J, Silverwood RJ, et al. Associations of blood pressure in pregnancy with offspring blood pressure trajectories during childhood and adolescence: findings from a prospective study. J Am Heart Assoc. 2015;4:e001422. doi: 10.1161/ JAHA.114.001422

20. Yang Q, Zhang Z, Zuklina EV, et al. Sodium intake and blood pressure among US children and adolescents. Pediatrics. 2012;130:611-619. doi: 10.1542/peds.2011-3870

21. Le-Ha C, Beilin LJ, Burrows S, et al. Oral contraceptive use in girls and alcohol consumption in boys are associated with increased blood pressure in late adolescence. Eur J Prev Cardiol. 2013;20:947-955. doi: 10.1177/2047487312452966

22. Samuels JA, Franco K, Wan F, Sorof JM. Effect of stimulants on 24-h ambulatory blood pressure in children with ADHD: a double-blind, randomized, cross-over trial. Pediatr Nephrol. 2006;21:92-95. doi: 10.1007/s00467-005-2051-1

23. Wiesen J, Adkins M, Fortune S, et al. Evaluation of pediatric patients with mild-to-moderate hypertension: yield of diagnostic testing. Pediatrics. 2008;122:e988-993. doi: 10.1542/peds. 2008-0365

24. Kapur G, Ahmed M, Pan C, et al. Secondary hypertension in overweight and stage 1 hypertensive children: a Midwest Pediatric Nephrology Consortium report. J Clin Hypertens (Greenwich). 2010;12:34-39. doi: 10.1111/j.1751-7176.2009.00195.x

25. Anyaegbu EI, Dharnidharka VR. Hypertension in the teenager. Pediatr Clin North Am. 2014;61:131-151. doi: 10.1016/ j.pcl.2013.09.011

26. Gandhi B, Cheek S, Campo JV. Anxiety in the pediatric medical setting. Child Adolesc Psychiatr Clin N Am. 2012;21:643-653. doi: 10.1016/j.chc.2012.05.013

27. Farpour-Lambert NJ, Aggoun Y, Marchand LM, et al. Physical activity reduces systemic blood pressure and improves early markers of atherosclerosis in pre-pubertal obese children. J Am Coll
Cardiol. 2009;54:2396-2406. doi: 10.1016/j.jacc.2009.08.030

28. Li JS, Baker-Smith CM, Smith PB, et al. Racial differences in blood pressure response to angiotensin-converting enzyme inhibitors in children: a meta-analysis. Clin Pharmacol Ther. 2008;84: 315-319. doi: 10.1038/clpt.2008.113

29. Singer PS. Updates on hypertension and new guidelines. $A d v P e-$ diatr. 2019;66:177-187. doi: 10.1016/j.yapd.2019.03.009

30. Torrance B, McGuire KA, Lewanczuk R, et al. Overweight, physical activity and high blood pressure in children: a review of the literature. Vasc Health Risk Manag. 2007;3:139-149.

31. DASH eating plan. National Heart, Lung, and Blood Institute. Accessed April 26, 2021. www.nhlbi.nih.gov/health-topics/dasheating-plan

32. Nutritional goals for age-sex groups based on dietary reference intakes and dietary guidelines recommendations (Appendix 7). In: US Department of Agriculture. Dietary guidelines for Americans, 2015-2020. 8th ed. December 2015;97-98. Accessed April 26, 2021. https://health.gov/sites/default/ files/2019-09/2015-2020_Dietary_Guidelines.pdf

33. Asghari G, Yuzbashian E, Mirmiran P, et al. Dietary Approaches to Stop Hypertension (DASH) dietary pattern is associated with reduced incidence of metabolic syndrome in children and adolescents. J Pediatr. 2016;174:178-184.el. doi: 10.1016/ j.jpeds.2016.03.077

34. Damasceno MMC, de Araújo MFM, de Freitas RWJF, et al. The association between blood pressure in adolescents and the consumption of fruits, vegetables and fruit juice-an exploratory study. J Clin Nurs. 2011;20:1553-1560. doi: 10.1111/ j.1365-2702.2010.03608.x

35. Anderson KL. A review of the prevention and medical management of childhood obesity. Child Adolesc Psychiatr Clin N Am. 2018;27:63-76. doi: 10.1016/j.chc.2017.08.003

36. Kumar S, King EC, Christison, et al; POWER Work Group. Health outcomes of youth in clinical pediatric weight management programs in POWER. J Pediatr. 2019;208:57-65.e4. doi: 10.1016/ j.jpeds.2018.12.049

37. Gregoski MJ, Barnes VA, Tingen MS, et al. Breathing awareness meditation and LifeSkills ${ }^{\circ}$ Training programs influence upon ambulatory blood pressure and sodium excretion among African American adolescents. J Adolesc Health. 2011;48:59-64. doi: 10.1016/j.jadohealth.2010.05.019

38. Escape Trial Group; Wühl E, Trivelli A, Picca S, et al. Strict bloodpressure control and progression of renal failure in children. $N$ Engl J Med. 2009;361:1639-1650. doi: 10.1056/NEJMoa 0902066

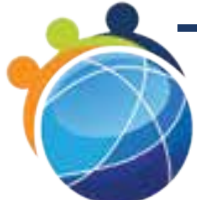

\section{MEDJOBNETWORK, $\mathrm{COm}$}

Physician • NP/PA Career Center

\section{The first mobile job board for Physicians, NPs, and PAs}

\section{Mobille Jolb Searches - access MedJobNetwork.com on the go from your smartphone or tablet}

Advanced Search Capabilities - search for jobs by specialty, job title, geographic location, employer, and more 